\title{
Economy Digitalization in Germany and Russia: Ethical Aspect
}

\author{
Borisova A.A.* \\ Philosophy and History Department \\ Voronezh State University of Engineering Technologies \\ Voronezh, Russia \\ E-mail: allaborisova@yandex.ru
}

Miroshnichenko E.N.

Foreign Language Department

Voronezh State University of Engineering Technologies

Voronezh, Russia

E-mail: emirosh79@gmail.com

\author{
Neshenko A.V. \\ Intercultural Communication Department \\ South Federal University \\ Rostov-on-Don, Russia \\ E-mail: 2290305@mail.ru
}

\author{
Borisov D.N. \\ Information Systems Department \\ Voronezh State University \\ Voronezh, Russia \\ E-mail: brsvdn@yandex.ru
}

\begin{abstract}
The purpose of the work is a complex analysis of the ethical component of the digitalization process in Germany and Russia. As a result of the study, the following tasks were solved: the German economic model for the development of a digital society was presented and explained in the framework of the Digital Strategy project; five stages of the conditions and the goals evolution of German digitalization were identified and analyzed; the essence and digitalization concepts in Germany were revealed; it is proposed to consider digitalization in Germany as a unity of social, political and economic processes; it is noted that Germany completely ignored the ethical aspect of digitalization, in connection with what the process of digitalization itself is recognized as completed. The presented model of the digital society development in Russia, operating within the framework of the Digital Russia project, is recognized as anthropocentric and environmentally friendly in relation to an individual. It is noted that the approach to the problems associated with digitalization in Russia can only be individual, and not legally stereotyped. The causes of digitalization distrust in Russia were analyzed. The problem of the lack of clear and structured research aimed at identifying, analyzing, predicting the risks of ethical problems existence is solved through the method of "vice versa brainstorming'. Four groups of ethical problems of digitalization in Russia were identified and explained: civil, social, professional and personal. A sociological survey and a statistical analysis of the processing of the obtained data were carried out. These methods allow solving the problem of the inability to analyze the ethical aspect of digitalization in Russia, taking into account the age, professional characteristics of the individual within the framework of a functioning ecosystem.
\end{abstract}

Keywords - information technology revolution, digitalization, economic development model, the project "Digital Economy, the program" Industry 4.0", the ecosystem of the digital economy, "vice versa brainstorming".

\section{INTRODUCTION}

The development of information and communication technologies (ICT) has led to an information technology revolution that has changed culture, science and technology.
Scientific knowledge, on one hand, becomes the public domain, that serves to increase society welfare, and on the other hand, creates a threat to the future. Inattention to the negative consequences of scientific and technological development, underestimation of the strength of society's expectation from science useful results, economic opportunities and momentary solutions to problems lead to social disasters. Despite the obviousness that there are positive and negative consequences, while using any technological achievement, they are extremely difficult to predict.

Digitalization, as a universal process of digital transformation, is one of the trends in world development that has affected the life of society at all levels (market regulation, law, business), and it is based on the introduction of new economic models, a total change in the production and management process, leads to the widespread technic digitalization, whith out databases and a man role through information technology. Digitalization as the basis of urgent modernization claims to be an important component of the long-awaited economic "breakthrough". At this stage of development, a unique historical chance is provided to create the conditions for a large-scale and effective digital transformation of the economy. However, digital technologies irrevocably change not only the world, but also the person who is developing and improving. The started mechanism of changes can not be stopped or reversed, and in view of the sharp, breakthrough nature of development, digitalization is gaining an increasingly powerful impetus.

\section{DIGITALIZATION IN GERMANY}

The German economic model for the digital society development is initially the reflection of domestic political events taking place in the country. Politicians are aimed at identifying and realizing the main voters desires and needs. The German community is unhappy with Germany's lagging behind world standards. In this regard, 2017 was marked by the universal digitalization of education, the labor market, public administration, healthcare, cities and regions network 
infrastructure [1]. The reform taking place in 2017 even affected the Bundeswehr digitalization (rotobization). The first digitalization and modernization agreements were signed between Russian and German concerns ("WILO SE" - LLC "WILO RUS"; "Rosneft Deutschland GmbH" - "Rosneft").

The German economic development program related to digitalization is aimed at implementing the leading economic tasks of the government - increasing labor productivity, increasing competitiveness, and raising living standards of citizens through the possibilities of digital transformation. The goal of digitalization in Germany is the digital strategy introduction that would implement the tandem digitalization of German economy and society. Therefore, in all official sources in 2017, digitalization is constantly declared as the guarantor of growth, competitiveness and welfare, and Germany is believed to be the leader of digitalization in Europe. It should be noted that in this case, the desired is given as valid.

Digitalization in Germany, rapidly carried out thanks to the total impact of society on politics, and politics on the economy, went through a series of stages of evolution conditions and goals in 2014-2017.

The first stage (2014). This stage turned out to be a failure, since the state fully counted on attracting private business finances by showing it privileges, which neutrality the European Union insisted on. In addition, during the forum "Digital Network Alliance of Germany", held by the Ministry of Transport and Infrastructure with the aim of attracting investments for innovations introduction, the exact sources and volumes of financial support for the development of digital infrastructure were kept in the dark.

The "Digital Agenda 2014-2017" [2] describes the conditions for the digital infrastructure development, digitalization of the German economy and society, and without specifying the sources of financing for project activities, without any specificity and with the help of streamlined language, it proclaims the digitalization of industry as a necessary stage of development, in particular, the implementation of "Industry 4.0" program which was announced in 2011. Digitalization support in the areas of labor, public services, dialogue with the public, science, education, culture, as well as security at the national and international levels is not supported by promises, despite the declared participation of the Ministry of Economy and Energy, the Ministry of the Interior and the Ministry of Transport and Digital infrastructure.

The second stage (2015). This stage was implemented within the framework of the information and communication technology project "Digital Germany 2015" [3], implemented by the government with the support of the Ministry of Economics and Technology, and aimed at providing legal support to citizens and creating jobs necessary for digitalization.

The third stage (2016). According to the project "Digital Strategy 2025" [4], supported by the Ministry of Economy and Energy, a transition to a new level of digitalization was announced by 2025 - the integration of a man, technology and processes into a united information and communication network. The "Ten Steps" were carried out. The main one was the promotion of startups, the revision of conditions for investments and innovations, security, modernization in the industry, continuous digital education, the creation of an agency coordinating a digitalization policy [5]. A critical assessment of critics noted the prevalence of strategies over their really necessary number and the fact that they will not pay off at any level in connection with the course taken for too rapid expansion [6].

The fourth stage (2016). The Federal Ministry of Transport and Digital Infrastructure during the "Network Alliance" forum [7] reviewed the future strategy of "Gigabit Germany" (Zukunftsoffensive Gigabit-Deutschland), which offered a structured universal introduction of the high-speed Internet in the country (the end of 2018), fiber-optic Internet (the end of 2019 years), 5-G networks (the end of 2020). The structuring should be completed by the end of 2025. This stage was distinguished by the publication of information on the share of state funding in the project and was very successful. Germany ranked 15 th in competitiveness and 8 th in terms of readiness for digitalization.

The fifth stage (2017). According to the statistics, Germany turned out to be the 4th country in the world (out of the 35 countries) studied by the degree of involvement in digitalization, but showed average results (in average the 17th place) when assessing private achievements: research level and manufacturability (the 16th place), business modeling (15th place), infrastructure development (the 19th place), the share of the educational sector digitalization (the 17th place). All the achievements of Germany in the field of digitalization required a rethinking of their concepts, equipment upgrades, large and long-term state investments. For example, school education needed financial support for the next 5 years (about 3 billion euros annually), and its current needs were only $50 \%$ satisfied by regional, community or parental investments [8]. The Federation announced its readiness to help the lands in the question of schools digitalization, however, still not fully [9].

Despite the fact that Germany's unwillingness to use the advantages of digitalization and the inconsistency of theory with practice became apparent, a course was taken towards universal digitalization from all areas of life: medicine, infrastructure at all levels, education, the labor market, and government. This was announced at the Summit (June 2017), dedicated to the prospects, challenges, the future of the digital economy and digital technologies, by a number of businessmen, politicians, trade unions, scientists. The stake was made on investments by enterprises, small and mediumsized businesses. Digitalization has been declared to be the priority aspect of public policy. The previous failures were associated with a lack of adaptability and business flexibility. In fact, it was a wary attitude and business distrust to the digitalization process [10].

Starting from 2018, the poorly concealed struggle with the costs of digitalization ended in Germany [11]. It becomes obvious that it is impossible to develop sustainable development programs. There is a choice of the best programs available without taking into account the moral aspect. Since 
2018-year, digitalization in Germany can be recognized as successful. Being aware of the current situation, Germany begins propaganda of digitalization in the world in connection with the focus on maintaining the digital level and the need for growth in economic development. The German digital economic development model, based on three mutually motivating pillars (society-politics-economics), turned out to be self-deception.

\section{DIGITALIZATION IN RUSSIA}

Due to the fact that Russia model of economic development is aimed not only at the living standards improving, but also at preventing social and other disasters within the framework of democratic freedom; the signing of the national project "Digital Economy" in 2017 by the Chairman of the Government of the Russian Federation D. Medvedev [12] caused a public outcry. The project proclaimed that Russia digital state policy is aimed at increasing Russia competitiveness, improving the quality of life of citizens, ensuring economic growth and national sovereignty. The project has been declared to be the part of "The strategy for Information Society Development in the Russian Federation for 2017-2030" [13], its purpose is to develop a knowledge society in the Russian Federation, to increase the welfare and quality of life of citizens, to increase awareness and digital literacy, access to services, security within the country and beyond its borders. The creation of ecosystem of the digital economy in the Russian Federation is represented at 3 levels - market and industry (service providers and consumers interaction), technological (formation of competencies on platforms), regulatory (information security), the last two are basic. This program involves the trinity of the state, business and science, the stuff demands (the lack of specialists at the appropriate level), the lack of global research of the world significance are the constraining factors for the program harmonious functioning [13].

Despite the rapid growth in mastering digital skills, the overall level of digitalization in Russia is below the world level (the 38th place) [12]. , On one hand, this is due to the huge difference in the level of digital skills of different population groups (age, professional, regional differences), and, on the other hand, to the presence of individual points indicating ethical obstacles and threats in the digital development program that hamper digitalization in Russia.

There is no doubt that the lack of trust in digitalization is also due to the lack of relevant regulatory legal and legislative acts that can eliminate these restrictions [12].

Two circumstances are obvious. Firstly, the process of digitalization in Russia, following the economic system as a whole, is anthropocentric and environmentally friendly in relation to an individual. Secondly, the approach to the problems associated with digitalization can only be individual, and not legally stereotyped, taking into account the age, professional, regional characteristics of the individual within the framework of a functioning ecosystem [14]. Thus, despite the fact that digitalization is becoming a top priority for many heads of Russian companies and, of course, one of the most fashionable words in Russia at the moment, it is legitimate to talk about the existence of an ethical cluster in the economic ecosystem of Russia as a whole and within the framework of digitalization [15].

\section{PRACTICAL METHODOLOGY}

The lack of clear and structured research aimed at identifying, analyzing, predicting the risks of the ethical problems existence associated with digitalization in Russia, prompted the authors of this article to turn to sociological methods of data collection: "vice versa brainstorming", a sociological survey, statistical processing and evaluation of the data obtained. This part of the article involves a step-bystep review of each of the claimed methods (the essence of the method, implementation conditions, stages, data obtained). The analysis of the data is devoted to the next section of the study. "Vice versa brainstorming" is a method of freely making unstructured decisions by a team. Four participants (the authors of this article), who are of the same age, being the specialists in the same field of knowledge development, in the process of spontaneously expressing ideas within the framework of the given topic "Ethical Problems of Digitalization in Russia", managed to generate12 problems within 2.5 hours. It should be noted that the value of this method lies in the free and critical expression of one's own ideas, as well as active discussion of other people's views. In this regard, in the process of formulating each of the problems, two stages were identified: the expression of the idea and its analysis. At the first stage, one of the participants in "vice versa brainstorming" names the problem which is obvious for him. At the second stage, another participant (at clockwise) expresses his attitude as an opponent to this problem, and the other two participants act as arbitrators and are called upon to record in writing the most successful of the proposals received during the discussion. It should be noted that the most interesting problems were expressed when it was difficult to generate the following problem. As a result of applying this method, each of the participants acted in one of the three roles: an idea generator, an opponent, and an arbiter. More than 20 ideas were expressed and the arbitrators fixed the priority of 10 of them. Then, a numbered list of issues was compiled. Each participant was asked to group problems according to certain criteria. In the process of expressing ideas, the team came to the conclusion that it is necessary to use the "Iapproach", in which attention is focused on the position of my "I", and to identify the global nature of the problem in terms of my interests and my vision. Four groups of problems were identified: 1) civil ("I as a citizen of the world"); 2) public ("I as a society member"); 3) professional ("I as a professional"); 4) personal ("I as a person").

\section{A. Civil issues}

The first problem is the national economic security of the country, every second there is a collision with the threat of cyber attacks in the process of society digitalization. Financial losses arise due to the inclusion of the national economy in the global digital "series" with an insufficiently developed level of digitalization. The losses of Russian economy from cyber attacks in 2019 amounted upto 2.5 trillion rubles [16]. As the 
number of cyber attacks increases, so does the damage they cause. If in 2018 the losses of companies in various sectors of the economy amounted to \$ 1.5 trillion, then in 2019, according to the forecast of Sberbank, they will have already reached 2.5 trillion. By 2022, according to the World Economic Forum forecast, the amount of planetary damage from cyber attacks could grow upto $\$ 8$ trillion [17]

The second problem is the total control over privacy, as a result of violating the boundaries of confidentiality and privacy in the process of identifying and preserving user digital data. Information about each person, including his private life, becomes publicly available. [18].

\section{B. Social issues}

The first problem is discrimination, infringement of the rights of the certain population groups in connection with professional, regional, age and other differences of citizens of Russia, non-compliance with the principles of social equality and social justice.

The second problem is asociality caused by the substitution of reality by manipulations in the virtual world in connection with the ideality and limitless possibilities of the latter. The level of digital technology development erases the line between reality and virtual world. A deficit of "a person to person" live communication appears in the world, which leads to speech and thinking defects, behavioral abnormalities, and manifests itself in an inability to control actions, analyze situations, anticipate events, and establish causal relationships. The abuse of digital technology is directly proportional to the highest level of intelligence decline [19]. This is explained by the easy access to knowledge; memorization, remembering a large amount of information, solving logical problems, comprehending and analyzing information, and much more, that was a kind of training and stimulating the work of all parts of the brain - these are all things of the past. Scientists of the Hartford University (USA), based on experimental studies, predicted a drop in the IQ level of an average person from 88.6 in 2010 to 83.8 by 2100 [20].

The third problem is gadget addiction. The creation of "digital I" leads to the fact that a person from an early age is dependent on the Internet, social networks; a person can not imagine himself without gadgets in which his whole life passes. If the use of the Internet and gadgets is unavailable, hysteria, aggression, a feeling of helplessness and other dysfunctions in human behavior may occur [21]

\section{Professional issues}

The first problem is the increase of unemployment and the lack of personnel demand. As a result of the artificial intelligence introduction, about $70 \%$ of mid-level managers of Sberbank in the Russian Federation were reduced [22].

The second problem is the unjustified disappearance of traditional humanitarian professions from the life of society due to uselessness, despite the growing need of society for specialists with interdisciplinary abilities and the ability to think critically.

\section{Personality issues}

The first problem is the transformation and gradual leveling of ethical standards and values, the result is the change in professional ethics. In the provision of medical, legal, educational services, a "digital" intermediary appears, a robot with the artificial intelligence.

The second problem is the loss of interest to a human personality. The real person is less and less interested in the new world order due to the sharp increase in the value of his double - the "digital avatar". The program of the Russian Federation Government to create an environment for the digital platform of public administration includes minimization of a human factor. The digital system, technology, but not a man, comes to the fore in the era of the fourth industrial revolution. A person is excluded from the process of collecting, analyzing and results processing. Technology forms an information field independent of a man. The main role in the world is played by technologies that become a full-fledged element of the market system.

The third problem is the change in cultural values attitudes toward oneself, towards others, towards society, towards nature, towards the Universe [23-24].

Further analysis of the four groups stated and discussed above, including ten ethical problems of the digitalization development in Russia, became possible thanks to the use of a kind of sociological survey as a questionnaire method.

The purpose of the questionnaire on the topic "Digitalization in Russia: the ethical aspect" is to identify a detailed and a comprehensive collective, group and public opinion on the ethical issues of digitalization. 506 students and teachers of the Voronezh State University of Engineering Technologies (Humanitarian specialties), Voronezh State University (Technical specialties), Southern Federal University (Rostov-on-Don) (Humanitarian specialties) took part in the questionnaire. The majority of the students being interviewed (53\% of boys and $47 \%$ of girls) belong to the age group from 18 to 22 years $(80 \%)$, teachers (52\% of men and $48 \%$ of women) - from 30 years and older $(20 \%)$. When conducting the questionnaire, the authors of the article stated three tasks: 1) to identify the percentage ratio of the proposed four groups of digitalization ethical problems (civil, social, professional, personal) that disturb Russian public (teachers and students); 2) to determine the relationship between the allocation of digitalization ethical problems with age (18-20 years, older than 30 years); 3) to determine the relationship between the allocation of digitalization ethical problems with the profession (teachers) and specialization (students).

The survey took place in three stages. The first preparatory stage is the implementation of introductory interviews in order to clarify the objectivity of the questions formulating, received as a result of the "vice versa brainstorming".

The second main stage is a questionnaire. The respondents were offered an electronic online questionnaire. The questionnaire includes 10 judgments that need to be evaluated on a five-point Likert scale, expressing different (positive and negative) attitudes to the measured object. A respondent 
assesses his attitude to each judgment: 1) national security of the country; 2) a threat of total control; 3) population discrimination; 4) asociality; 5) dependence on gadgets; 6) unemployment; 7) disappearance of professions; 8) transformation of ethical values and norms; 9) loss of interest to a person; 10) change in cultural values.

The third final stage is the processing of the obtained data using the SPSS Statistics program. According to the results of the study, statistical data presented below in the form of a diagram and two histograms were obtained that were not previously publicly available.

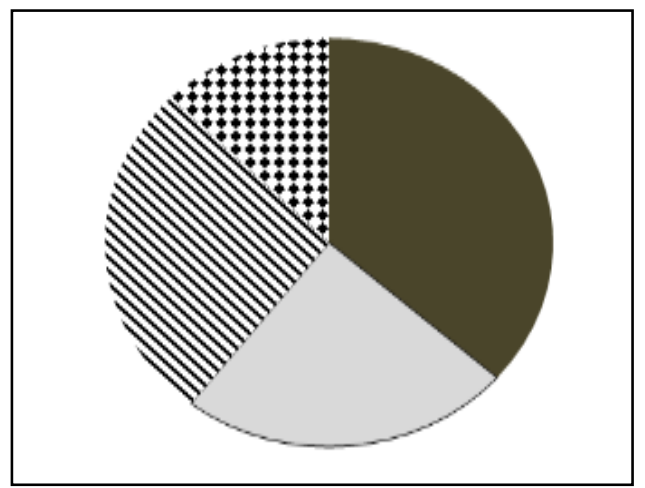

Fig. 1. Ethical problems of digitalization in Russia

The circular diagram shown in fig. 1, reflects the percentage of the proposed four groups of ethical problems of digitalization (civil, social, professional, personal). $36 \%$ of the respondents (the 1st place) are concerned about the civil ethical problems of digitalization in Russia (national security of the country and the threat of total control), $26 \%$ (the second place) - worry about professional ethical problems (unemployment, loss of profession), $24 \%$ (the third place) are concerned about public ethical problems (population discrimination, asociality, gadgets dependence), $12 \%$ (the fourth place) - are puzzled by personal ethical problems (transformation of ethical values and norms, loss of interest to a personality, changes of cultural values).

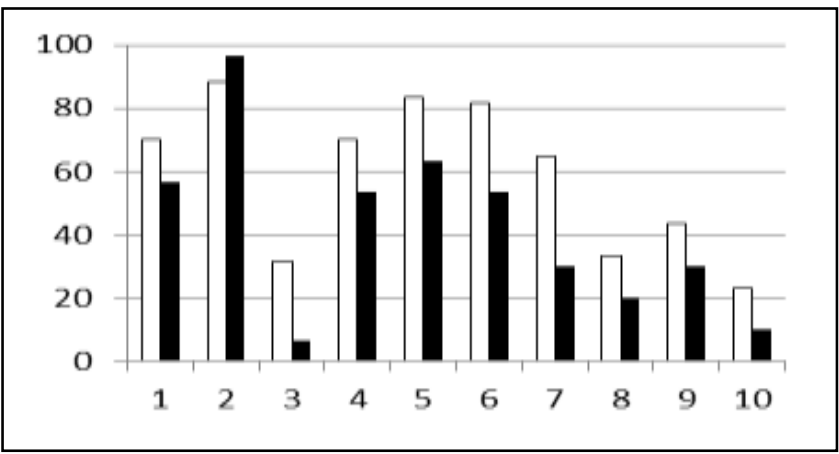

Fig. 2. Digitalization ethical issues of people due to their different ages in Russia: white color - teachers, black color - students.

The histogram (Fig. 2) reflects the teachers and students attitude in percentage to the mentioned above 10 ethical issues of digitalization in Russia. The degree of teachers concerns on nine $(1,3-10)$ of the ten ethical issues is higher than the degree of students excitement by 10 that is $35 \%$. The most urgent problem for both students and teachers is the civil ethical problem of total control (2), and only in this indicator the degree of students concerns $(97 \%)$ is higher than teachers one $(88 \%)$. In the second place for both studied groups there is a social problem of gadgets dependence (students - $62 \%$, teachers $-82 \%$ ). Both teachers and students are primarily concerned about civil and social problems (the exception is the social problem of population discrimination). The personal ethical problems are in the last place for both age groups.

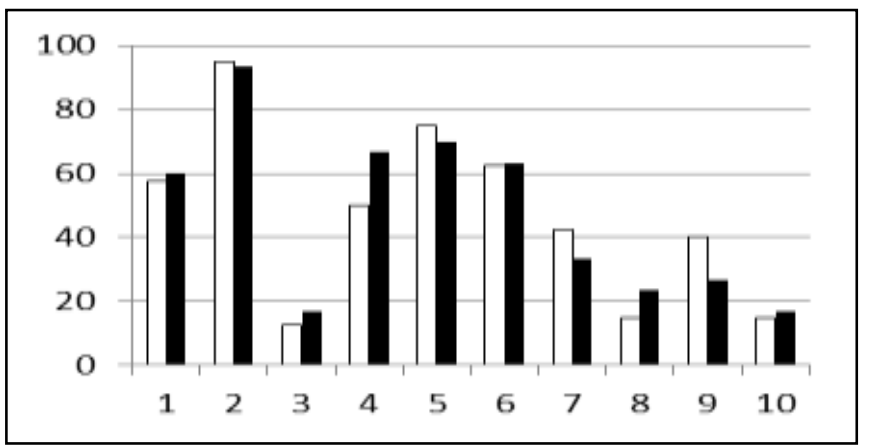

Fig. 3. Ethical problems of digitalization in Russia: professional perspective: white color - Technical education, black color - Humanitarian education

The histogram shown in figure 3, reflects the teachers and students' percentage of Technical and Humanitarian areas to the identified above ethical problems of digitalization in Russia. The degree of concerns for the ethical problems of digitalization among teachers and students of humanitarian areas (further referred as 1 group of the respondents) is higher in six out of ten problems $(1,3-4,6,8,10)$ than in technical areas (further referred as the second group of the respondents) by $2-20 \%$. The first group of the respondents is concerned about the social problem of asociality (4) (67\%), while the second group, to a slightly greater extent than the first one, is concerned about the professional problem of unemployment and civil ethical problem of the country's national security.

The methodological set of techniques and methods, stated in this part of the article for the practical study of the digitalization ethical problems in Russia, has been fully implemented. The data obtained experimentally serve as a way of practical transformation, objectification, and deepening of the theoretical research of the problem presented above. It creates the basis for an in-depth analysis of the results.

\section{RESULTS}

Based on the theoretical and practical data highlighted above, the following discoveries were made regarding the ethical problems of digitalization in Russia.

There is no doubt about the objective existence of the identified four groups of digitalization ethical problems in Russia. The subjectivity of the results of the "vice versa brainstorming" method, due to the small number of participants, is absolutely neutralized during the survey.

The percentage of the four groups of ethical problems, the revealed features of the attitude towards digitalization by 
students and teachers, humanitarian and technical specialists are fully explained by Russia state policy.

36 percent of the Russians are concerned firstly with the civil ethical problems of digitalization and it is not accidental. The issue of national security is the leading regulatory component of the "Strategy for the Information Society Development in the Russian Federation for 2017-2030". The assignment of the second place out of the four to professional ethical problems of digitalization $(26 \%)$ is associated with the course taken by Russia towards the trinity - the state, business and science, the harmonious functioning of which depends entirely on the personnel issue. The presence of social ethical problems, which are indicated by $24 \%$ of the respondents, actively inhibits the digital skills mastering of the Russians and reduces the level of digitalization in Russia. The assignment of the last place to personal ethical problems $(12 \%)$ is associated with the complexity of the current political situation in Russia and the need to resolve primarily global issues that the Russian public is concerned about. However, it should be noted that the identified indicator of 12 $\%$ is a significant amount confirming the anthropocentric orientation of the Russian economy.

The apparent increased anxiety of middle-aged Russians compared with young people by $10-35 \%$ is due to the sharp changes in society that have befallen the older generation. The presence of negative personal experience, economic instability give rise to fears, worries for the future, based on the experience. The degree of students anxiety, as a rule, is not so high as that of teachers, and as a rule, lies not in the insufficient degree of consciousness and responsibility of young people, but in its realization of the fact that only a normal level of anxiety allows mobilizing strength and moving forward.

The excessive relevance of the civil ethical problem of total control among both age groups of the Russian population is explained by the fact that the level of digitalization development in Russia has reached the point when there is a violation of the main right guaranteed by the Constitution of the Russian Federation - the right to privacy. Information about a person is tracked on the basis of previously collected data using cameras, sensors, GPS navigators, identifiers, social networks. The total control system stores passport data, information about the date of birth, profession, hobbies, family status, health. Young people and the older generation are aware that the danger lies in the digital technologies ahead of legislative changes in the country.

The older generation in Russia perceives gadgets as dangerous latest technologies, a problem that negatively affects leisure (preference for gadgets), education (poor performance), health (sleep disturbance, energy abuse, inopportune meals) and they criticize young people for whom gadgets are originally familiar and are an integral part of life. The presence and not far-fetchedness of the social problem of gadgets dependence is confirmed by the recognition of its existence by young people.

Modern Russian society, being a tribute to the world fashion, is experiencing a conflict of humanitarian and technical specialists. Specialists in technical areas are deeper
(2-20\%) aware of the problematic nature of the digitalization process, as they are engaged in its implementation. Humanitarian specialists are concerned about the asociality processes that they observe, primarily among specialists of technical areas. Enormous regret is caused by the state policy of the Russian Federation aimed at supporting preferably technical specialties. Of course, specialists in technical specialties ensure economic and industrial growth. However, it is the humanities who are more concerned about the presence of ethical problems, since they are engaged in the study of various forms of culture manifestation by type of activity and ensure the social society development.

\section{CONCLUSION}

Widespread digitalization is a megatrend that has touched all spheres of social life in the 21 st century. At first glance, it seems that each country has its own morality and its own vision of the digitalization process. In fact, it is quite obvious that the more developed the country is, the deeper the digitalization and the higher the risks when integrating information systems with the public. There are 3 degrees of digitalization implementation: full digitization and the presence of startups; reactive digitization in the presence of start-ups (gravitation towards old systems); passivity in digitization (conservatism).

In Germany, politics was called upon to normalize relations between science and society. Science has become an instrument of politics, a mean of achieving sustainability in development. It has gone beyond the boundaries of individual disciplines and has penetrated the social sphere. Knowledge turned out to be socially relevant, became a support for making political, social decisions. The analysis of the German economic model for the digital society development showed that the German strategy is aimed at total digitalization in any way, without regard to ethics.

The rapid evolution of the digital space in Russia requires a change in the attitude to ethical issues in the context of globalization and digitalization. It became apparent that ethical issues in Russia could not be resolved through laws of jurisprudence. Public acceptance of digitalization in Russia is possible if there are two components: recognizing of the risks existence, implementing credible citizens social policies that accompany digital transformation. The course taken by the Russian government on environmental friendliness and anthropocentricity is recognized as the only right one. Introduced digital technology should serve, but not harm a person. It is extremely dangerous to pass the point of no return, to which the post-industrial world community is recklessly striving. The strategy against to technologicalization and total consumerism is needed, which should be built on consciousness and responsibility for the future of our nation and humanity as a whole.

\section{References}

[1] V.B. Belov, Germany. 2017. Moscow: Instit. of Europe RAS, 2018 , pp. 34-114

[2] Digitale Agenda 2014-2017, Bundesministerium für Wirtschaft und Energie, Bundesministerium des Innern, Bundesministerium für Verkehr 
und digitale Infrastruktur, August 2014. Retrieved from: https://www.digitale-agenda.de/Content/DE/_Anlagen/2014/08/201408-20-digitale-agenda.pdf;jsessionid=481E078EB51F8C539D 855635E0FBA3E4.s3t2?_blob=publicationFile $\& \mathrm{v}=6$.

[3] IKT-Strategie der Bundesregierung "Deutschland Digital 2015", Bundesministerium für Wirtschaft und Technologie (BMWi), Berlin, November 2010. Retrieved from: https://www.dstgb.de/dstgb/ Homepage/Schwerpunkte/Breitbandinfrastruktur/Archiv/ \%22Deutschland \%20Digital \%202015 \%22/Digital \%20Strategie \%202015.pdf

[4] Digitale Strategie 2025, Bundesministerium für Wirtschaft und Energie (BMWi), Berlin, März 2016. Retrieved from: http://www.bmwi.de/Redaktion/DE/Publikationen/DigitaleWelt/digitale-strategie-2025.pdf?_blob=publicationFile \&v $=18$.

[5] Zehn Fakten zum Breitbandausbau Blog.Telekom. Retrieved from: https://www.telekom.com/de/blog/konzern/artikel/zehn-fakten-zumbreitbandausbau-500994 (access mode: 23.08.2017)

[6] O. Falck, A. Mazat, "Breitbandausbau in Deutschland: "Need for Speed? Wie viel ist genug? Breitbandausbau in Deutschland"”, Schnelldienst, vol. 69 , no. 20 , s. $26,2016$.

[7] Eckpunkte Zukunftsoffensive Gigabit-Deutschland. Retrieved from: http://www.bmvi.de/SharedDocs/DE/Anlage/DG/eckpunktezukunftsoffensive.pdf?_blob=publication File

[8] A. Breiter, A. Zeising, B. Stolpmann, IT-Ausstattung an Schulen: Kommunen brauchen Unterstützung für milliardenschwere Daueraufgabe. Bertelsmann Stiftung, 2017.

[9] Innovation sindikator 2017, Bundesverband der Deutschen Industrie. Berlin, Juni 2017. Retrieved from: http://www.innovationsindikator.de/ fileadmin/2017/PDF/Innovationsindikator_2017.pdf

[10] IMD World Digital Competitiveness Ranking 2017. IMD World Competitiveness Center, p. 89.

[11] V.B. Belov, Germany. 2018. Moscow: Instit. of Europe RAS, 2019, pp. $15-100$.

[12] The order of the Government of the Russian Federation of 28 July 2017, no. 1632-r "On approval of the program" Digital Economy of the Russian Federation".
[13] The decree of the President of the Russian Federation dated 9 May 2017, no. 203 "On the Strategy for the Information Society Development in the Russian Federation for 2017-2030".

[14] Y.M. Sokolinskaya, E.A. Kolesnichenko, "Criminalization as a main threat to economic security", Proc. of the Voronezh State Univer. of Engineer. Technol., vol. 81, no. 1, pp. 480-484, 2019.

[15] M.Y. Afanasiev, M.A. Lysenkova, "Approach to the analysis and comparison of national innovation systems on the example of Russia and other countries", Proc. of the Voronezh State Univer. of Engineer. Technol., vol. 81, no. 1, pp. 434-442, 2019.

[16] O. Matys, "The Russian economy suffered 2.5 trillion rubles from cyber attacks in a year", Komsomolskaya Pravda, January 21, 2020.

[17] 33 ways Davos 2019 made an impact on the world. 25.01.2019. Retrieved from: https://www.weforum. org/agenda/2019/01/shaping-thefuture-at-davos-2019

[18] A.V. Babaeva, A.A Borisova, R.A Cherenkov, Information Society and Applied Informatics Problems: History and Present. Voronezh: Voronezh State Univer. of Econ., 2019, 60 p.

[19] L.A. Saenko, M.V. Egorov, "Internet space as a factor of forming the network community", Istoricheskaya i sotsial'noobrazovatel'naya mysl, vol. 1, pp. 159-162, 2015.

[20] S.I Kretov, "Will Digitalization Lead Russia's Economic System to Prosperity?", Lomonosov Readings-2019, vol. 3, pp. 115-117, 2019.

[21] I.D. Afanasenko, V.V. Borisova, "Digital Economy and Socio-Ethical Values,” Bull. of St. Petersburg State Univer. of Econ., vol. 5, no. 113, pp. 7-11, 2018.

[22] I. Zhandarova, "Sberbank reduced $70 \%$ of managers due to artificial intelligence", Rossiyskaya Gazeta, 10.11.2018.

[23] A. Babaeva, ""Go there I don't know where": axiological trajectories in the modern world", Inform. Communicat. Society, pp. 28-34, 2018 [Proc. of the sci. conf., 2018].

[24] A. Babaeva, "Axiological transformation: the Russian trend", Modern probl. of the Human. and soc.1 Sci., vol. 3, pp. 5-10, 2016. 